\title{
Urban sprawl facilitates invasions of exotic plants across multiple spatial scales
}

\author{
Francesco Boscutti $\odot$ - Francesco Lami • Elisa Pellegrini • \\ Massimo Buccheri • Francesco Busato • Fabrizio Martini • Rossella Sibella • \\ Maurizia Sigura $\cdot$ Lorenzo Marini
}

Received: 3 December 2020 / Accepted: 19 January 2022 / Published online: 3 February 2022

(C) The Author(s) 2022

\begin{abstract}
Exotic plant invasions are considered one of the major threats to biodiversity causing important impacts at the population, community, and ecosystem levels. Understanding the drivers of plant invasions across multiple spatial and temporal scales often requires a landscape approach. The effect of landscape composition on biological invasion has been extensively studied, whereas landscape configuration effects were seldom considered or the analyses were
\end{abstract}

Supplementary Information The online version contains supplementary material available at https://doi. org/10.1007/s10530-022-02733-6.

F. Boscutti $(\bowtie) \cdot$ F. Lami · E. Pellegrini · M. Sigura Plant Biology Unit, Department of Agricultural, Food, Environmental and Animal Sciences, University of Udine, via delle Scienze 91, 33100 Udine, Italy

e-mail: francesco.boscutti@uniud.it

E. Pellegrini

Department of Biology, University of Copenhagen, Universitetsparken 4, 3rd floor, 2100 København Ø, Denmark

M. Buccheri

Museo Friulano di Storia Naturale di Udine, via Cecilia Gradenigo Sabbadini, 22-32, 33100 Udine, Italy

F. Busato $\cdot$ R. Sibella $\cdot$ L. Marini

DAFNAE, University of Padova, Viale dell'Università 16,

35020 Legnaro, Padova, Italy

F. Martini

Trieste, Italy limited to single species. Here, we aimed to analyze how the expansion of urban and agricultural areas can affect exotic species richness (both neophytes and archaeophytes) at three spatial scales, namely regional (scale: $37.5 \mathrm{~km}^{2}$ ), landscape (scale: $7.1 \mathrm{~km}^{2}$ ) and local (scale: $100 \mathrm{~m}^{2}$ ). We considered the possible contribution of urban and agricultural areas both in terms of composition (i.e. habitat cover) and configuration (i.e. shape complexity of patches). First, we found that increasing urbanization coupled with high shape complexity of urban elements were major drivers of both neophyte and archaeophyte invasions across heterogeneous landscapes. In particular, shape complexity seemed to be a key driver of plant invasions at large spatial scale, whereas the type of recipient habitat and urban cover determined the exotic success at the patch level. Second, archaeophytes were also affected by agriculture land use, i.e. agricultural patches shape complexity increased their spread at both regional and landscape scales. High shape complexity of highly disturbed habitats is expected to increase the exchange surface that exotic plant use to spread their propagules across the landscape mosaics. Our findings suggest that urban planning aimed at curbing urban fragmentation by both reducing shape complexity and diffuse urban sprawl might greatly improve the resistance of landscapes to biological invasions.

Keywords Alien plants · Fragmentation · Landscape configuration · Urbanization 


\section{Introduction}

Exotic plant invasions are considered one of the major threats to biodiversity (Vilà et al. 2010; Simberloff et al. 2013; Vilà and Hulme 2017; Pyšek et al. 2020) causing important impacts at the population, community and ecosystem levels (Vilà et al. 2011; Boscutti et al. 2020; Pellegrini et al. 2021a). Understanding the drivers of plant invasions across multiple spatial and temporal scales often requires a landscape approach (Vilà and Ibáñez 2011). First, the role of landscape composition, i.e. proportion of landscape covered by different habitats, has received increasing attention, as human-impacted landscapes are expected to harbor a larger pool of exotic species and increase the likelihood of propagule dissemination to natural areas (Jauni and Hyvönen 2010; Basnou et al. 2015; Andersen et al. 2015; Pellegrini et al. 2021b). Anthropogenic land-uses such as agricultural and urban habitats represent primary sources of alien plants by providing empty niches released from competition with natives (Lonsdale 1999; Davis et al. 2000; Vilà et al. 2007; Polce et al. 2011; Boscutti et al. 2018). In particular, urban land use encompasses a large array of disturbed habitats (e.g. roadsides, gardens) that are usually highly invaded (Chytrý et al. 2008; Lambdon et al. 2008; Aikio et al. 2012) and that can act as source of exotic plants that can spread into surrounding habitats (Lippe and Kowarik 2008; Botham et al. 2009; Säumel and Kowarik 2010; Kühn et al. 2017; Guo et al. 2019). While most of these studies have focused on landscape composition, the effects of landscape configuration of urban and agriculture areas have been seldom investigated empirically (but see Chen et al. 2017; O'Reilly-Nugent et al. 2016).

Landscape configuration effects have been mostly investigated to study plant invasions within natural fragmented habitats embedded in intensive matrices (Hastings et al. 2005). This body of research showed that small fragments usually have a higher density of exotic species than larger fragments (Guirado et al. 2006; Ohlemüller et al. 2006), and that an increase in exotic plant density, richness and cover is often observed at the edge between natural habitats and more intensive land-uses such as urban or agricultural areas (Cilliers et al. 2008; Boscutti et al. 2018). These results suggest that increased patch shape complexity is expected to promote the spread of exotic plants across human-impacted landscape mosaics (Yates et al. 2004; Song et al. 2005; Malavasi et al. 2014). In particular, landscapes with large contagion, high shape complexity and high patch density are expected to promote exotic invasions by increasing the dispersal opportunities of exotics between urban areas and the surrounding habitats and the availability of disturbed edges (Aikio et al. 2012; Bar-Massada et al. 2014). Upscaling the effect of spatial configuration from the habitat level to the whole landscape is an urgent task to predict the effect of land-use changes on plant invasions across multiple spatial scales.

When evaluating the drivers of exotic plant invasions, it is important to consider how these effects vary across spatial scales (Stohlgren et al. 2006; Pauchard and Shea 2006; Foxcroft et al. 2009). Most of previous studies adopting a multi-scale approach has focused on the relationship between native and alien species richness (Campos et al. 2013), whereas only a few have tested for scale-dependence in the effect of abiotic drives of plant invasions (but see Cabra-Rivas et al. 2016). At broad spatial scales, climate, soil and habitat types are expected to be more influential in determining species distribution (Araújo et al. 2005; Guisan et al. 2006; Bailey et al. 2017) while at finer scales, disturbance and biotic interactions should become more important (Bartuszevige et al. 2006; Milbau et al. 2009).

In the European floras, the status of exotic plants is commonly further classified into two categories: archaeophytes (i.e. plants introduced before 1500) and neophytes (i.e. plants introduced after 1500). Archaeophytes and neophytes often exhibit consistent distribution patterns, suggesting that similar mechanisms can be responsible for their spread (Chytrý et al. 2008). Nonetheless, archaeophytes are often ruderal or segetal species mainly linked to agricultural land uses (Chytrý et al. 2008; Sheppard and Brendel 2021; Zając et al. 2009), while neophytes are expected to be more related to urban areas. In this light, studying the response of these two groups to landscape composition and configuration might provide further insight into the invasion mechanisms.

In this study, we aim to analyze how the expansion of urban and agricultural areas can affect exotic species richness (i.e. neophytes and archaeophytes) at three spatial scales, namely regional (scale: $37.5 \mathrm{~km}^{2}$ ), landscape (scale: $7.1 \mathrm{~km}^{2}$ ) and local (scale: $100 \mathrm{~m}^{2}$ ). We considered the possible contribution of urban and agriculture areas both in terms 
of composition (i.e. habitat cover) and configuration (i.e. patch shape complexity) (Fig. 1). We hypothesize that increasing cover of urban areas and increasing shape complexity will increase invasion of exotic species across the landscape by increasing colonization opportunities linked to disturbance and by facilitating dispersal of exotic plants across the interface where human settlements adjoin or intermix with other ecosystems. We also expect that these effects should be stronger for neophytes than for the more agriculturedependent archaeophytes.

\section{Materials and methods}

Sampling design and data collection

The study area was located in the Friuli Venezia Giulia region in north-eastern Italy $\left(45^{\circ} 44^{\prime} 56^{\prime \prime} \mathrm{N}\right.$, $12^{\circ} 59^{\prime} 56^{\prime \prime} \mathrm{E}$ to $46^{\circ} 11^{\prime} 52^{\prime \prime} \mathrm{N}, 13^{\circ} 29^{\prime} 56^{\prime \prime} \mathrm{E}$; Fig. 2). The area is characterized by an average annual temperature of $13{ }^{\circ} \mathrm{C}$ and an average annual rainfall between 1100 and $1600 \mathrm{~mm}$. The most frequent crops were maize, soybean, winter cereals (mostly barley and wheat) and grape. Several towns are located in the study area: Udine (ca. 100,000 inhabitants), Pordenone (ca. 50,000), Cordenons (ca. 18,000) and Codroipo (ca. 16,000).

The diversity patterns of exotics (i.e. neophyte $=$ post -1500 immigrants; archaeophytes $=$ pre1500 immigrants) in the study region (ca. 3,000 $\mathrm{km}^{2}$ ) was studied at three spatial scales: (i) regional (ii) landscape (iii) local habitat. First, the whole area was split into a regular grid of 83 cells, each of $3^{\prime} \times 5^{\prime}$ (arcmin), corresponding to ca. $35.7 \mathrm{~km}^{2}$ (i.e. regional scale) (Fig. 2). Within each grid cell, exotic species distribution was extracted from an ongoing floristic inventory of the Friuli Venezia Giulia, which contained over 290,000 records collected in the period 1980-2017. Second, 15 circular landscapes (ca.
Fig. 1 Representation of tested gradients of landscape composition (e.g. cover of urban areas) and configuration (e.g. shape complexity of urban elements) at regional scale, land use considered were: urban (dark grey), agricultural (green) and seminatural (white)

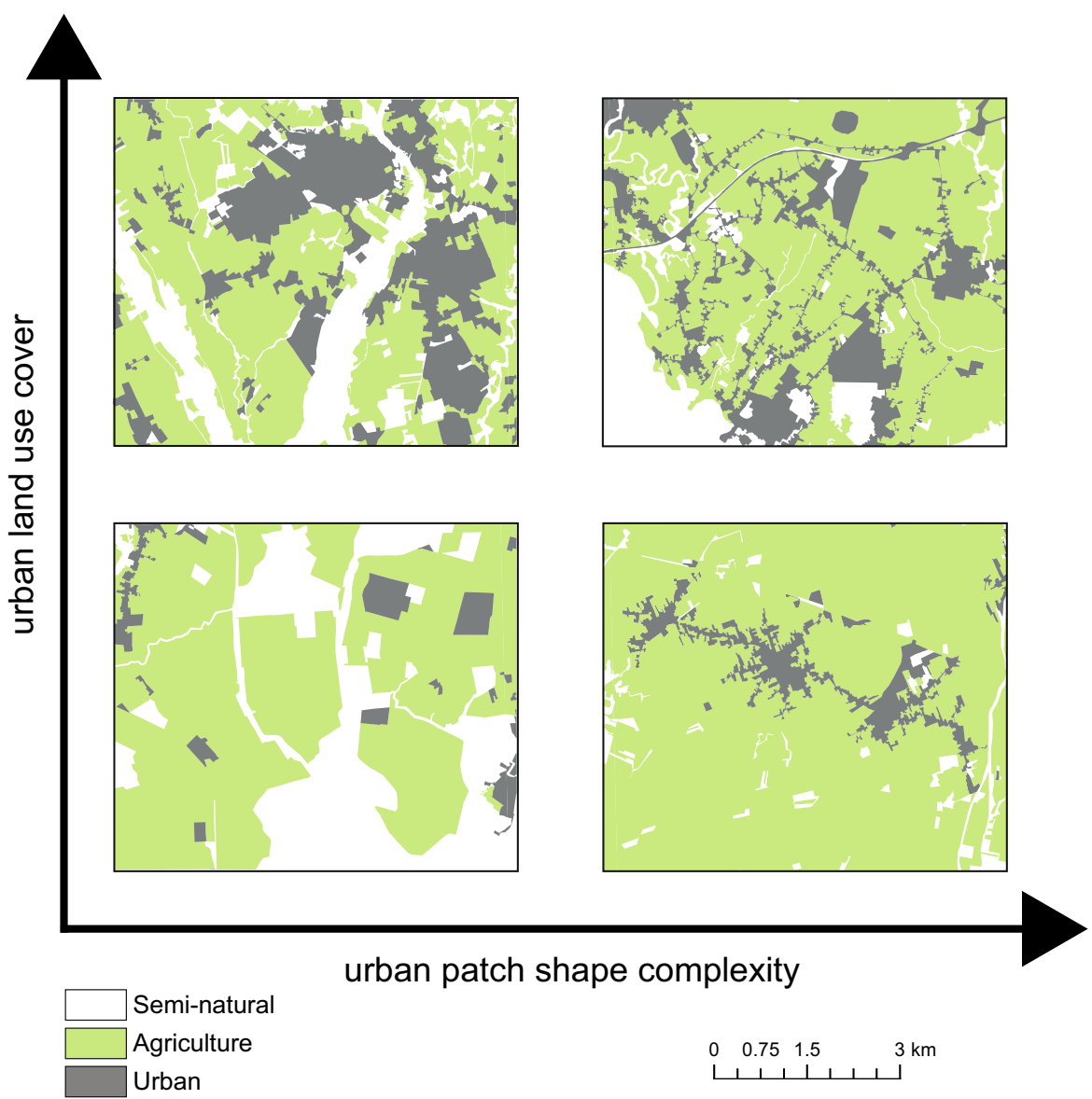



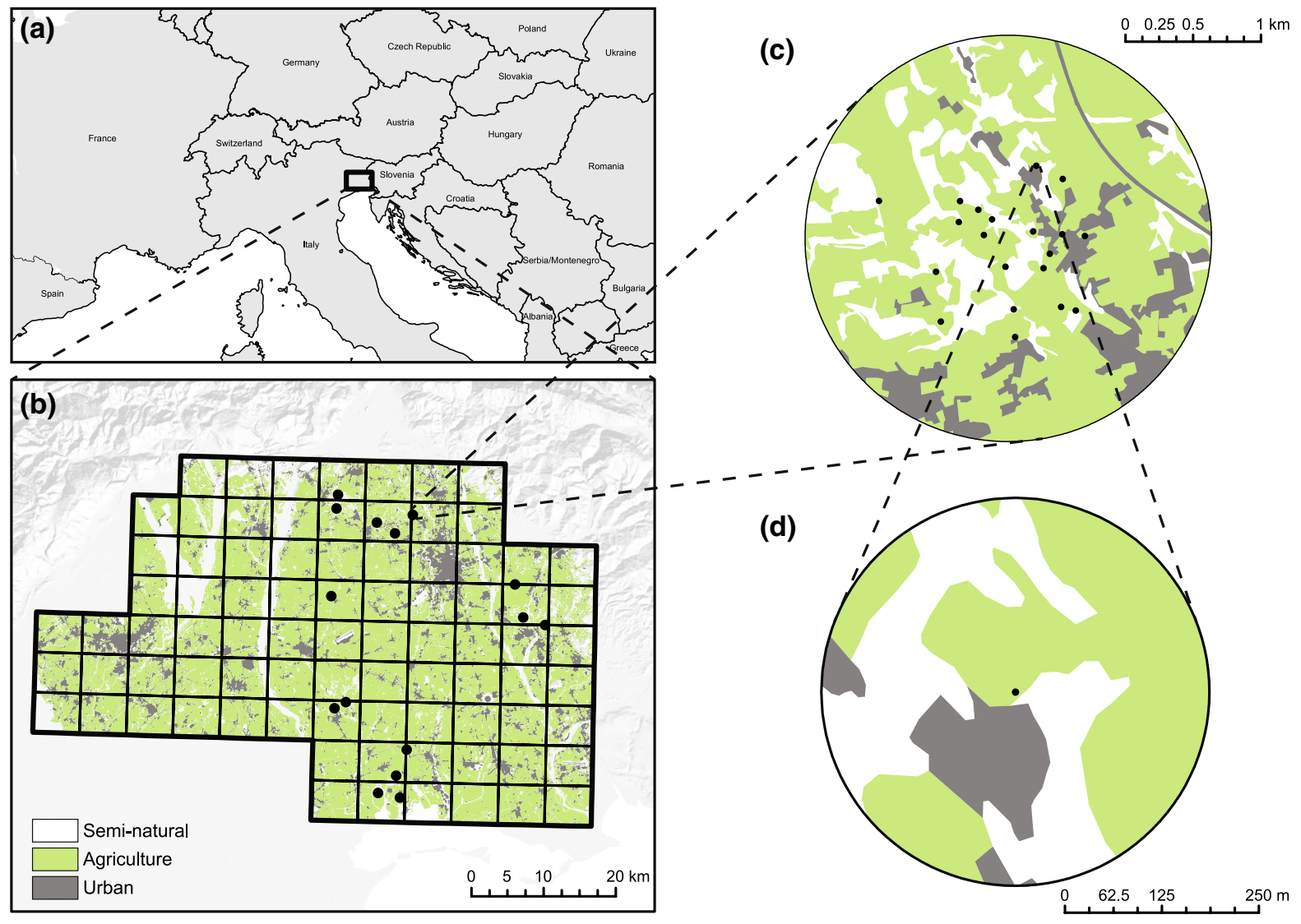

Fig. 2 Study area (a) and sampling design at regional (b), landscape (c) and local (d) scale. Urban (dark grey), agricultural (green) and semi-natural land uses (white) are represented at each scale

$7.1 \mathrm{~km}^{2}$, radius $=1.5 \mathrm{~km}$; i.e. landscape scale) were selected along gradients of urban cover and patch density after a preliminary analysis on existing land use maps (scale 1:25,000; IRDAT FVG, accessed March 2017). Urban cover and patch density were used as common proxies of land use intensification (Chaplin-Kramer et al. 2011; Lizée et al. 2012; Martin et al. 2016). For each landscape, a detailed land use map (scale 1:2000) was realized distinguishing agricultural (i.e. annual and perennial crops), urban and semi-natural habitat (i.e. forests hedgerows and meadows). In each landscape, 20 sampling points $(10 \times 10 \mathrm{~m})$ were selected for a total of $300(20 \times 15)$ plots for flora survey at local and landscape scale. Within each landscape, the number of points per habitat type reflected the relative abundance of the habitat. The surveyed habitat included both agricultural (i.e. annual crops, $\mathrm{N}=122$; perennial crops $\mathrm{N}=55$ ) and semi-natural habitats (forests, $\mathrm{N}=71$; hedgerows, $\mathrm{N}=13$; meadows, $\mathrm{N}=28$ ). The complete list of sampled habitats and number of plots per landscape can be found in supplementary materials (Online Resource 1). Plots were randomly distributed within each landscape excluding landscape edges. At this scale, we did not sample urban habitats (e.g. parks, gardens, yards), as we wanted to test the habitat and landscape invasibility of non-urban habitats. In summer 2017, all the plots were surveyed in the field recording all occurring vascular species. During the surveys, 11 plot were discarded due to accessibility issues.

Number of exotic species were calculated at the plot, landscape and regional scale by pooling species list at different spatial scales. Nomenclature followed the Italian check-list (Bartolucci et al. 2018; Galasso et al. 2018). Exotic status (i.e. neophyte and archaeophyte) was classified according to the regional checklists (Poldini 2002; Buccheri et al. 2019). 
Landscape metrics

Landscape composition and configuration were assessed at all investigated scales in terms of land-use cover and patch shape complexity using (i) the official regional land use map, for the regional scale (scale 1:25,000, IRDAT FVG, realized in 2017), and, (ii) the detailed land use maps realized for each of the 15 surveyed landscapes, for the landscape and plot scales. Landscape composition was quantified as cover of urban land use in each cell grid $\left(35.7 \mathrm{~km}^{2}\right)$ and landscape $\left(7.1 \mathrm{~km}^{2}\right)$. At habitat level, urban cover was calculated in a buffer with a radius of $250 \mathrm{~m}$ around each plot, which has been already proved to be a sensitive scale when analyzing exotic plant spread in similar landscapes (Kumar et al. 2006; Boscutti et al. 2018). Urban areas ranged between 1.9-57.3\%, $0.8-24.5 \%$ and $0.0-51.4 \%$ at the regional, landscape and plot scale, respectively. Arable land ranged between $26.8-92.4 \%, 46.4-97.9 \%$ and $0.3-100.0 \%$; at regional, landscape and plot scale, respectively. The cover of urban areas and agricultural land was not highly correlated at the three scales of analysis (regional, $r=-0.45$; landscape, $r=-0.21$; plot scale, $\mathrm{r}=-0.17)$.

Landscape configuration was assessed in terms of patch shape complexity by using the Area Weighted Mean Patch Fractal Dimension (AWMPFD) index (McGarigal and Marks 1995) for both urban and agriculture patches. The patch fractal dimension represents a comparison of the perimeter and area of each shape, similarly to the shape index, but testing the exponent of that relationship (Milne 1988). Fractal dimension is a measure of the complexity of shapes that gives more emphasis on the complexity of form while the common shape index stresses the elongation of patches. A fractal dimension greater than 1 for a 2-dimensional landscape mosaic indicates a departure from a Euclidean geometry (that is, an increase in patch shape complexity). AWMPFD approaches 1 for shapes with very simple perimeters, such as circles or squares, and approaches 2 for shapes with highly convoluted, plane-filling perimeters, this index is weighted by patch area so that larger patches weigh more than smaller patches. In the study, AWMPFD will be referred as shape complexity. All the analyses were performed using the Patch Analyst extension (C) for ArcGIS 10.0 (ESRI). Preliminarily, we also assessed other landscape configuration metrics, namely the total edge (TE), as the sum of the lengths (m) of all edge segments involving the corresponding patch type, and the Area-Weighted Mean Shape Index (AWMSI), an area-weighted index of shape complexity (McGarigal and Marks 1995). All indices showed a high correlation with AWMPFD $(r>0.5)$ at all scales and were therefore excluded from the analyses (Online Resource 2).

\section{Data analysis}

To explore the effects of landscape composition (proportion of urban and agriculture areas) and shape complexity at different spatial scales on exotic plant richness (i.e. neophytes and archaeophytes), Linear Models (LM) and Generalized Linear Models were run in R statistical environment (R Core Team 2020).

At the regional and landscape scale, we fitted a LM testing the effect of proportion of urban and agriculture areas and shape complexity on the species number of both neophytes and archaeophytes.

At the habitat scale, we fitted a generalized mixedeffects model with a Poisson distribution testing proportion of urban and agricultural areas and habitat type and their two-way interactions on the number of exotics (i.e. neophytes and archaeophytes) in the $10 \times 10 \mathrm{~m}$ plot. Then, we simplified the models by removing one-by-one the non-significant interaction terms $(p>0.05)$ using a manual backward selection procedure. We included landscape ID as random factor to account for the spatial dependence in the design. The interaction between shape complexity and habitat type was not tested at the plot scale, where the low number of patches did not allow a solid analysis of landscape configuration. Full models are shown in Online Resource 3.The model assumptions were checked using diagnostic plots of model residuals using the car and DhARMA packages in R. Due to the better residual diagnostics outcome, LMs were applied at regional and landscape scale even if species richness measures were counts.

\section{Results}

An overall number of 336 neophyte and 217 archaeophyte species were observed (Online Resource $4)$. At the regional scale, a mean of $61(\min =15$, $\max =145)$ neophytes and $80(\min =42, \max =158)$ 
archaeophytes were found. At the landscape scale, we found an average of $14(\min =7, \max =21)$ neophyte and $19(\min =11, \max =24)$ archaeophyte species. At the local habitat (plot) scale, the mean number was 2 for both neophytes $(\min =0, \max =9)$ and archaeophytes $(\min =0, \max =10)$. Most of the neophyte species were perennial $(62.2 \%)$, out of these $30.1 \%$ were woody species and $32.1 \%$ were grasses or forbs. Annual species represented the $37.8 \%$ of the neophyte flora. Archaeophytes were mostly annual plants (71.9\%). Among perennial archaeophytes, woody species accounted for only $2.3 \%$, while $25.8 \%$ were perennial grasses or forbs. The five top most frequent taxa at the regional scale were Erigeron annuus (L.) Pers., Veronica persica Poir., Robinia pseudoacacia L., Bidens frondosa L., Oxalis stricta L., for neophytes (occurrence in over the $90.0 \%$ of surveyed grid cells), and Anagallis arvensis L., Bellis perennis L., Cichorium intybus L., Digitaria sanguinalis (L.) Scop., Plantago lanceolata L. for archaeophytes (occurring in all the surveyed cells). At the local and landscape scale, the most frequent species were $A$. retroflexus, $P$. capillare, $R$. pseudoacacia and E. annuus, for neophytes (frequency $>15.0 \%$ ), and $A$. arvensis L. Chenopodium album L. and Echinochloa crus-galli (L.) P.P.Beauv among archaeophytes (frequency $>20 \%$ ).

Our findings highlighted scale-dependent effects of landscape composition and patch shape complexity on exotic species richness (Table 1). At the regional
Table 1 Results of the models testing the effects of urban and agriculture cover $(\%)$ and patch shape complexity (Area Weighted Mean Patch Fractal Dimension-AWMPFD) on neophyte and archaeophyte species richness at regional (a), landscape (b), and local (c) scale
At local scale, the interaction between patch shape complexity and habitat type was not considered

\begin{tabular}{|c|c|c|c|c|}
\hline Fixed effects & Estimate & SE & $\mathrm{t}$ value & $\mathrm{p}$ \\
\hline \multicolumn{5}{|l|}{ (a) Regional } \\
\hline \multicolumn{5}{|l|}{ Neophytes } \\
\hline Intercept & -196.07 & 71.47 & -2.744 & 0.008 \\
\hline Urban shape complexity & 169.06 & 51.14 & 3.306 & 0.001 \\
\hline Urban cover & 123.50 & 23.30 & 5.299 & $<0.001$ \\
\hline \multicolumn{5}{|l|}{ Archaeophytes } \\
\hline Intercept & -195.91 & 82.71 & -2.369 & 0.020 \\
\hline Urban cover & 128.25 & 19.82 & 6.472 & $<0.001$ \\
\hline Agriculture shape complexity & 188.30 & 61.03 & 3.085 & 0.003 \\
\hline \multicolumn{5}{|l|}{ (b) Landscape } \\
\hline \multicolumn{5}{|l|}{ Neophytes } \\
\hline Intercept & -81.98 & 35.65 & -2.300 & 0.040 \\
\hline Urban shape complexity & 70.55 & 26.77 & 2.635 & 0.022 \\
\hline Urban cover & 0.221 & 16.78 & 0.013 & 0.989 \\
\hline \multicolumn{5}{|l|}{ Archaeophytes } \\
\hline Intercept & -48.72 & 28.92 & -1.685 & 0.118 \\
\hline Agriculture shape complexity & 43.60 & 18.99 & 2.296 & 0.041 \\
\hline Agriculture cover & 14.52 & 8.96 & 1.621 & 0.131 \\
\hline \multicolumn{5}{|l|}{ (c) Local } \\
\hline \multicolumn{5}{|l|}{ Neophytes } \\
\hline Intercept & 0.84 & 0.23 & 3.698 & $<0.001$ \\
\hline Habitat type & -0.69 & 0.11 & -6.466 & $<0.001$ \\
\hline Urban cover & 0.86 & 0.47 & 1.820 & 0.060 \\
\hline Agriculture cover & 0.09 & 0.25 & 0.360 & 0.719 \\
\hline \multicolumn{5}{|l|}{ archaeophytes } \\
\hline Intercept & 0.65 & 0.24 & 2.739 & 0.006 \\
\hline Habitat type & -1.36 & 0.14 & -9.535 & $<0.001$ \\
\hline Urban cover & 1.55 & 0.56 & 2.786 & 0.005 \\
\hline Agriculture cover & 0.59 & 0.26 & 2.224 & 0.026 \\
\hline Habitat type: urban cover & 1.98 & 0.88 & 2.253 & 0.024 \\
\hline
\end{tabular}


scale ( $\mathrm{n}=83$ grid cells), we found both urban cover and urban shape complexity to have a positive effect on the number of neophytes (Fig. 3a-b). The model explained $37.3 \%$ of the total variation. Archaeophyte species richness increased in areas with high urban cover and agriculture shape complexity (Fig. 3c-d). The model accounted for the $44.1 \%$ of the total variation. At the landscape scale ( $\mathrm{n}=15$ landscapes), only shape complexity of urban and agriculture patches affected neophyte and archaeophyte species richness,

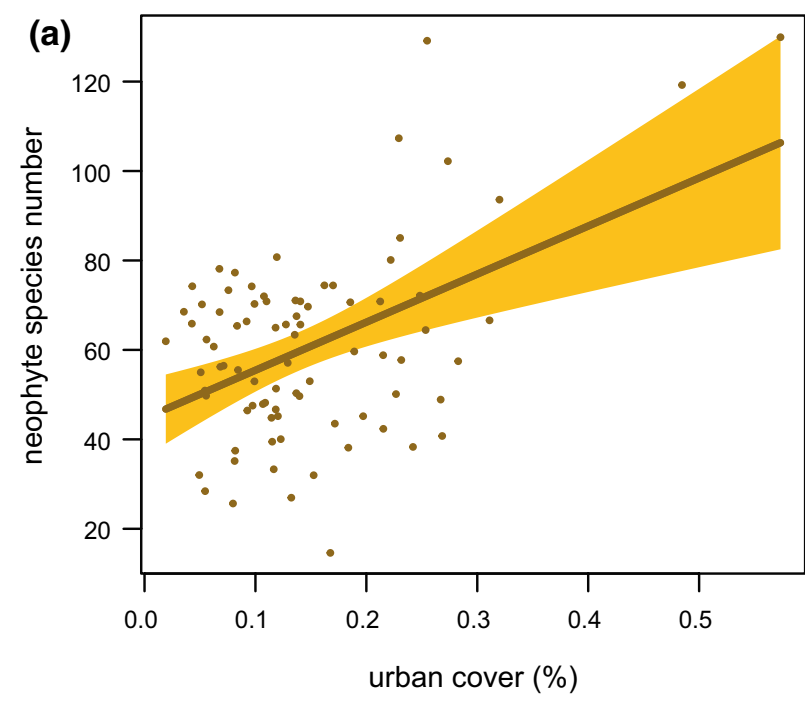

(c)

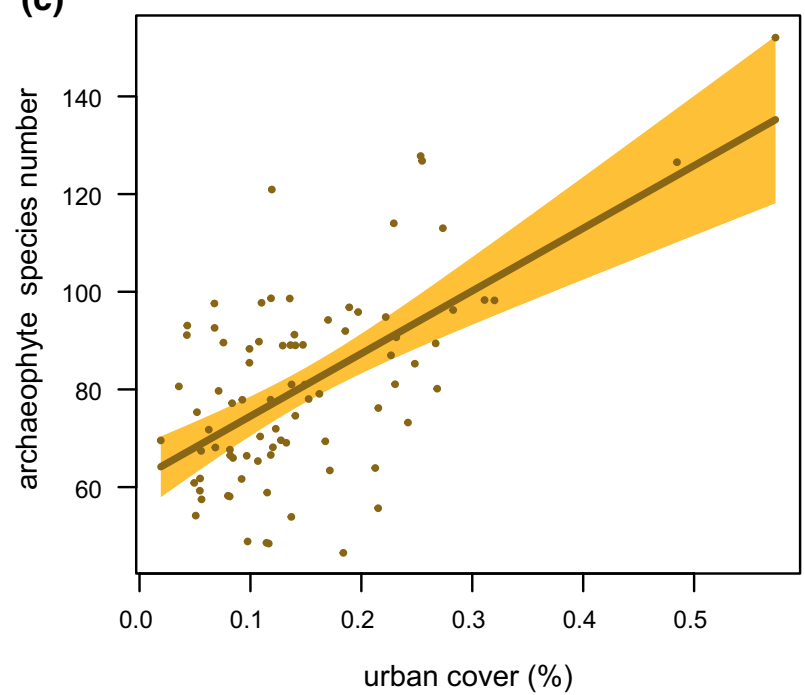

Fig. 3 Relationships between neophyte species number, urban cover (a) and urban shape complexity (b), and archaeophyte species number, urban cover (c) and agriculture shape com- showing a linear positive relationship (Fig. 4; neophytes: $\mathrm{R}^{2}=37.8 \%$, archaeophytes: $\mathrm{R}^{2}=19.7 \%$ ). At the local scale $(n=289$ plots $)$, semi-natural habitats were less invaded than agricultural ones for both neophyte and archaeophyte species (Fig. 5a-c). Neophyte species number increased in plots surrounded by high percentage of urban areas (Fig. 5b), irrespective of habitat type. Archaeophyte species number increased in plots surrounded by high percentage of both agriculture and urban areas (Fig. 5d-e). In particular,

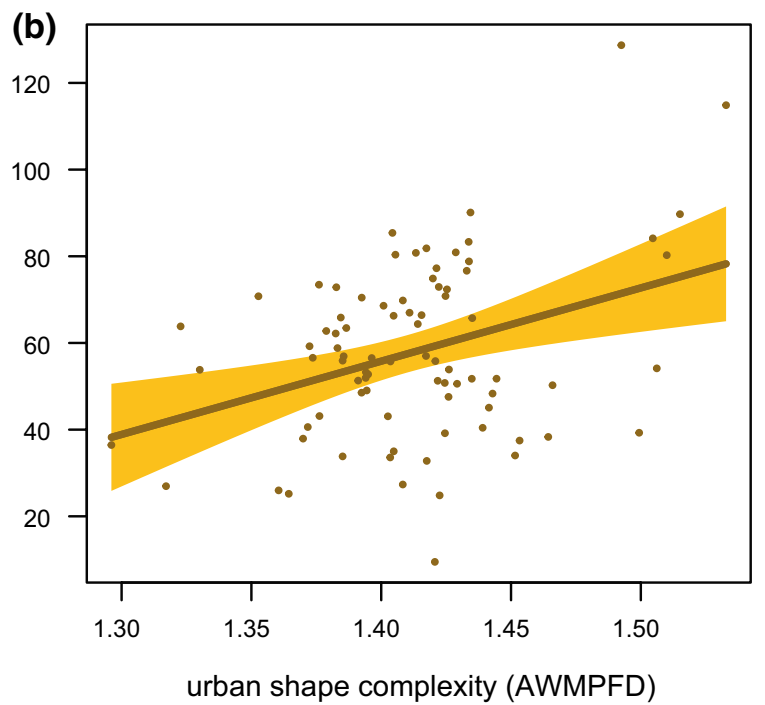

(d)

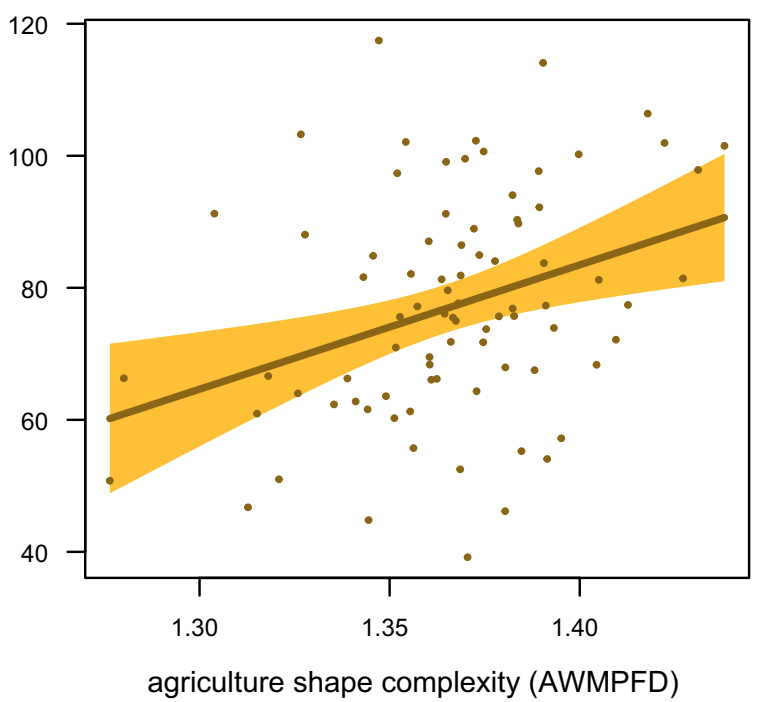

plexity (c), at regional scale. Shape complexity is expressed as Area Weighted Mean Patch Fractal Dimension (AWMPFD). Shaded area is the $95 \%$ confidence interval 


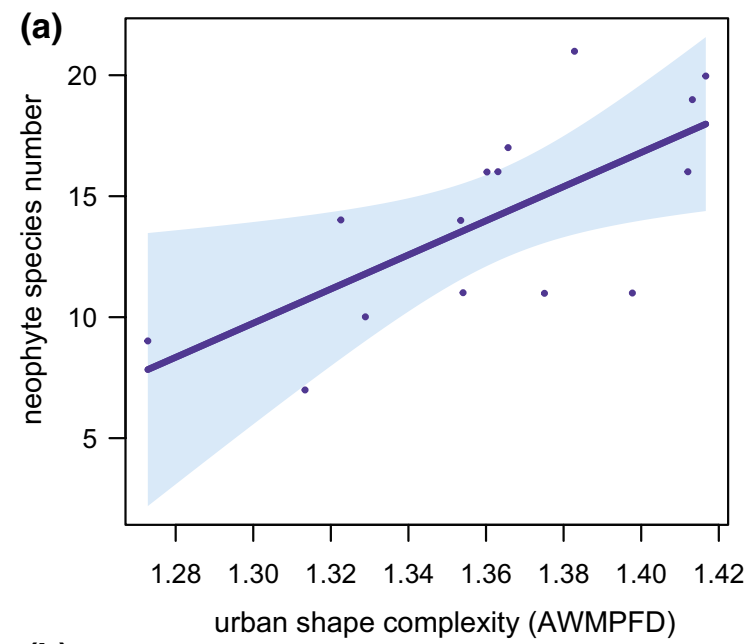

(b)

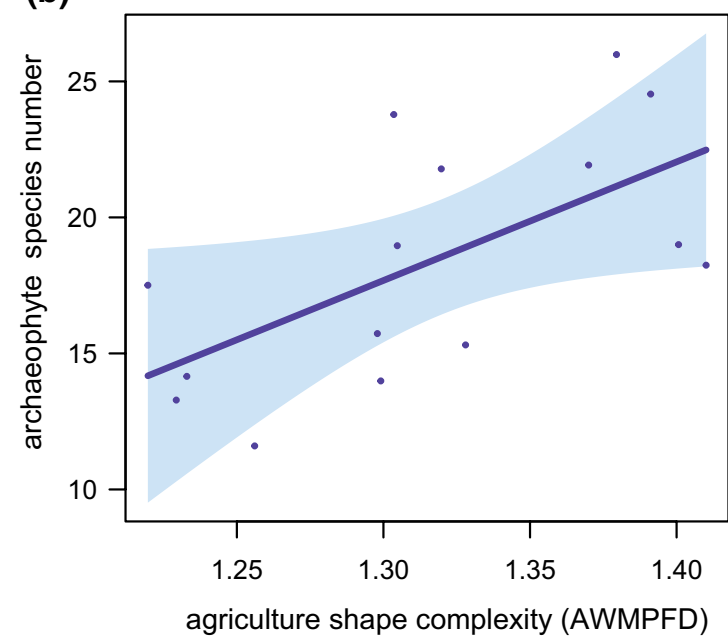

Fig. 4 Relationships between exotic species number (i.e. neophytes or archaeophytes) and shape complexity of urban (a) and agriculture (b) patches at landscape scale. Shape complexity is expressed as Area Weighted Mean Patch Fractal Dimension (AWMPFD). Shaded area is the $95 \%$ confidence interval

urban cover showed a stronger effects on archaeophytes invading semi-natural areas, when compared to agricultural ones (Fig. 5e).

\section{Discussion}

The contribution of landscape composition on biological invasion has been extensively studied, whereas landscape configuration has been seldom considered (Vilà and Ibáñez 2011) or limited to single species (Song et al. 2005; Montti et al. 2017). We found that increasing urbanization coupled with high shape complexity of urban elements were major drivers of neophyte invasions. In particular, shape complexity seemed to be the most important abiotic driver of plant invasions at large spatial scale whereas the type of recipient habitat and urban cover determined the exotic success at scale of habitat patches. Moreover, we found that increasing shape complexity further increased the spread of archaeophytes at both the regional and landscape scales.

At the regional scale, we found that both increasing urban cover and patch shape complexity contributed to increase the number of exotic species. Urban areas are often over-represented among the sites of first introduction due to high propagule pressure (Pyšek 1998; Chytrý et al. 2008; Aikio et al. 2012). Urban land use creates a mosaic of different humanmade habitats (e.g. roadsides, gardens) that are often highly invaded and that are expected to promote the spread of exotic species also to the surrounding habitats (Lippe and Kowarik 2008; Lambdon et al. 2008; Botham et al. 2009; Säumel and Kowarik 2010). A key role is played by roads that are often considered effective dispersal corridors (Arévalo et al. 2005; Follak et al. 2018; McDougall et al. 2018; Lázaro-Lobo and Ervin 2019). A high patch shape complexity in the landscape is generally associated with a low overall disturbance intensity but more diffused across the landscape matrix (Krummel et al. 1987; O'Neill et al. 1988), which in rural landscapes has been proved to favor overall plant species richness (Moser et al. 2002).

This pattern was even stronger at the landscape scale where we only found that shape complexity of urban and agriculture areas affected the spread of neophyte and archaeophyte plants species, respectively. This suggests a possible relationship between the success of spread and dispersal of exotic species and the configuration of the invasion foci (i.e. urban settlements for neophytes and arable land for archaeophytes). So far, a few studies have related plant invasion with landscape shape complexity and patch edge density (Bartuszevige et al. 2006; Kumar et al. 2006). Indeed, the shape complexity of urban areas might have amplified the exchange surface between habitats that neophytes use to spread their propagule across the landscape mosaics. A low-density of urban land-cover is often characterized by fragmented and disturbed natural areas within a loose matrix of 
gardening and housing areas (Gavier-Pizarro et al. 2010). This might produce a greater probability of exotic ornamental species to spread from gardens and urban areas into adjacent natural areas (GavierPizarro et al. 2010; González-Moreno et al. 2013). In the studied landscapes, small settlements (e.g. towns, villages), as well as suburbs of main urban centers, contributed to increase shape complexity. In contrast, large cities typically have a relatively small interface between urban and wildland ecosystems. Previous studies have indicated that the presence of numerous small towns scattered across the landscape have a greater chance of promoting invasions into natural areas than large cities (McLean et al. 2017). Moreover, a more complex settlement might harbor a greater heterogeneity of urban habitats, sustaining a high variety of exotic species propagules. Suburbs, small towns, linear corridors (e.g. streets, highways) harbor vast areas of ornamental gardens, flower beds and flower borders, source of at least $75 \%$ of the global naturalized alien species (Kleunen et al. 2018). Invasions of natural areas have been already linked to the presence of garden flora of the surrounding urban dwellings (Marco et al. 2010; Guo et al. 2019). In addition, urban shape complexity is also linked to a higher development of road network, which often determines the invasion success of exotic species within semi-natural habitats (Hansen and Clevenger 2005; Dainese et al. 2017; Riitters et al. 2018). In contrast to neophytes, the richness of archaeophytes at the landscape scale increased with high patch complexity of agricultural areas. Other studies showed that archaeophytes are more linked to agricultural than to urban land use (Chytrý et al. 2008). Our findings suggest that, at large spatial scale, increasing the exchange surface between arable land and seminatural habitats provide a greater chance for archaeophytes to spread across the territory. Previous studies have showed archaeophytes to be particularly common in landscapes with small fields rather than in landscapes dominated by large fields (Baessler and Klotz 2006).

At the local scale, we found that agricultural habitats (i.e. annual and perennial crops) were more invaded than semi-natural habitats by both neophyte and archaeophyte species. In general, highly humanimpacted habitats are widely recognized for their high level of plant invasion (e.g. Aikio et al. 2012; Chytrý et al. 2008; Lambdon et al. 2008; Maskell, Bullock,
Smart, Thompson, and Hulme 2006). At this scale also patch features might influence invasion (Milbau et al. 2009) and local variations in soil quality and vegetation structure might become pivotal in the invasion success (Ohlemüller et al. 2006; Vitti et al. 2020). Our findings suggest that urban areas may be the main source of exotic plant invasion toward other habitats. Invasion by exotic species often begins in human-disturbed environments, where their propagules are unintentionally introduced or where cultivated species frequently escape (Pyšek 1998; Hulme 2005; Čeplová et al. 2017; Geppert et al. 2021). Other studies showed that semi-natural habitats are more prone to be invaded when included in a urban- rather than agricultural-dominated matrix (Cilliers et al. 2008) and that at the local scale the proximity to roads might be pivotal in the invasion process (Zeeman et al. 2018). A consistent pattern was found for the two exotic groups when considering urban and habitat effects. In addition, archaeophytes were also favored by high agriculture cover in the surrounding of the plot (Preston et al. 2004). Our findings would suggest that arable land might be concurrently a source and a sink of archaeophyte plants (Hulme 2005), as it also emerged in studies on the effects of anthropic disturbance in agricultural landscapes (Boscutti et al. 2018).

\section{Conclusions}

Clarifying the mechanisms through which exotic species spread across the landscape might inform an effective management/planning aimed at curbing biological invasions. Our study elucidated how plant invasion was affected by alterations of landscape composition and configuration. We showed that urbanization was a major driver of plant invasions showing that its shape complexity of urban areas was fundamental in the process. In particular, landscape shape complexity seemed to be a facilitator of plant dispersal and spread at the landscape scale whereas the habitat characteristics and landscape composition determine the exotic success at the local scale. Such evidence suggests that urban planning should consider reducing urban fragmentation to reduce the exchange surface between anthropogenic and natural habitats. These results allow to gain a better understanding of the way landscape composition and 
(a)

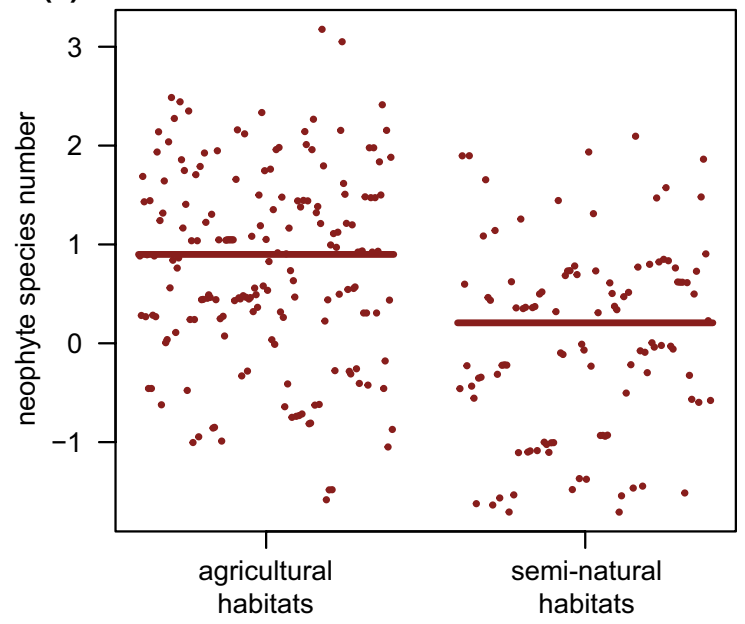

(c)
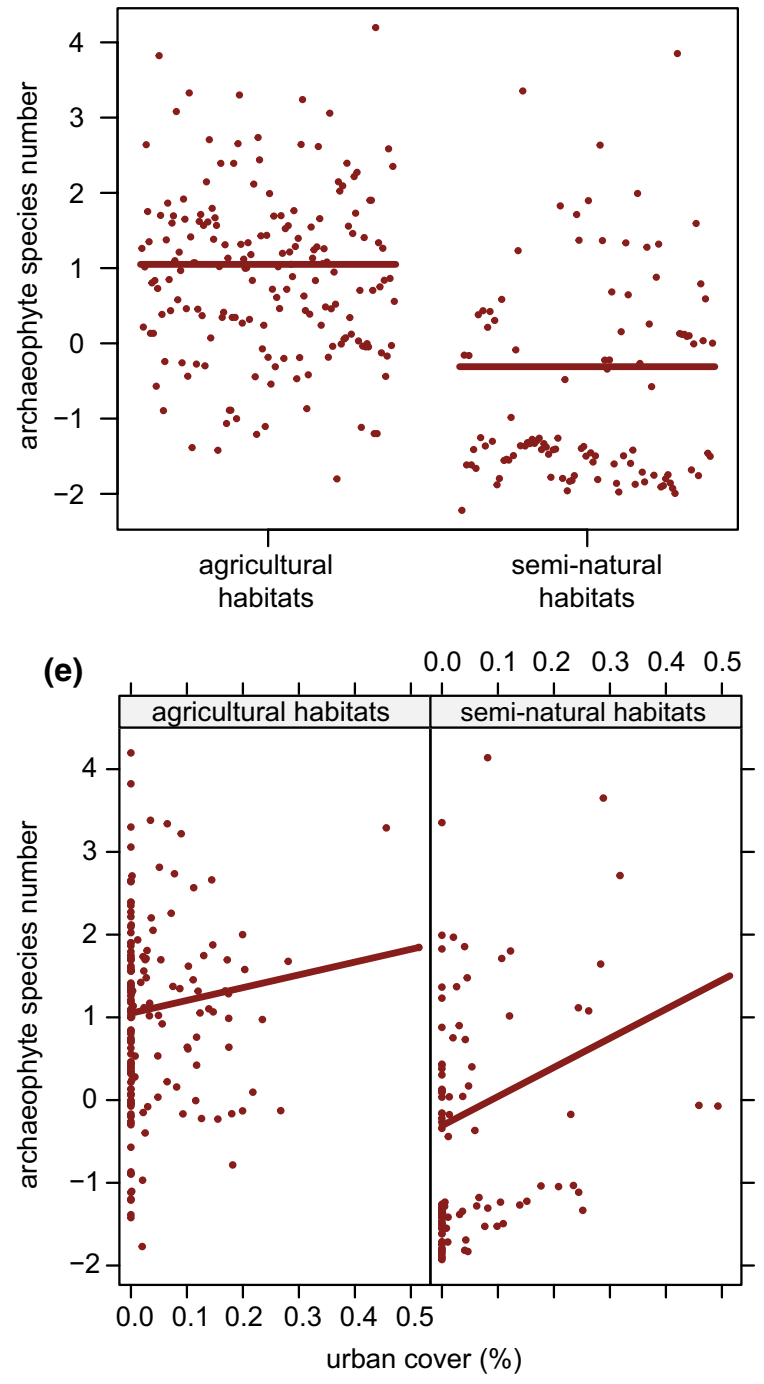

(b)

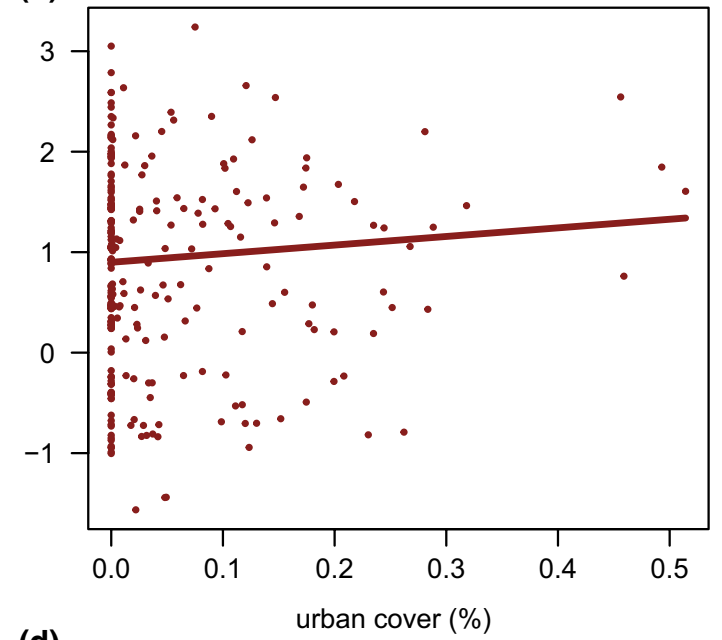

(d)

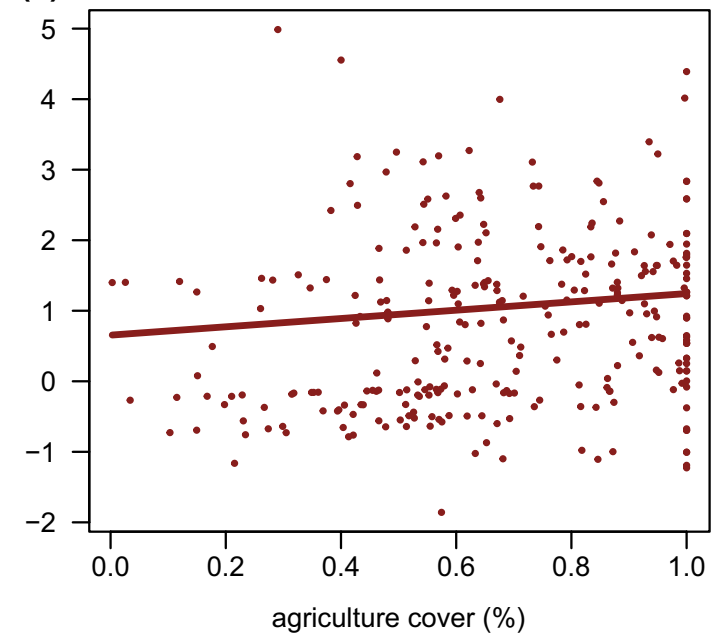


4Fig. 5 Relationships between neophyte species number, habitat type (a) and urban cover (b), and archaeophyte species number, habitat type (c), agriculture cover (d), and interaction between urban cover and habitat type (e), at local scale

configuration contribute in modifying plant invasions, providing far reaching consequences in invasion ecology and landscape planning.

Acknowledgements Authors would like thank all contributors to field data collection and in particular Gianfranco Bertani, Adriano Bruna, Antonino Danelutto, Roberto Pavan and Claudio Peruzovich. We thank to Anna Carpanelli and Marco Valecic for the profitable collaboration during the research project.

Authors' contribution FB: Conceptualization, Methodology, Investigation, Formal analysis, Writing-original draft. FL: Conceptualization, Methodology, Investigation. EP: Conceptualization, Methodology. MB: Resources, Investigation, Funding acquisition. FB: Investigation. FM: Investigation. RS: Investigation. LM: Conceptualization, Methodology, Formal analysis, Writing — original draft. All authors contributed to the interpretation of the results and the revision of the manuscript.

Funding This research was funded by Friuli Venezia Giulia Region. The study was also supported by the University of Padova through the project BIRD171833/17 "Predazione e mortalità naturale dei semi come strategia di controllo delle infestanti in agricoltura conservativa" to LM.

Data availability All data are accessible in Mendeley data repository: https://doi.org/10.17632/9yfs3x6crx.1 (Boscutti et al., 2022).

\section{Declarations}

Conflict of interest The authors declare that they have no known competing financial interests or personal relationships that could have appeared to influence the work reported in this paper.

Consent for publication All authors consent to the publication of the manuscript in Biological Invasion, should the article be accepted by the Editor-in-chief upon completion of the refereeing process.

Open Access This article is licensed under a Creative Commons Attribution 4.0 International License, which permits use, sharing, adaptation, distribution and reproduction in any medium or format, as long as you give appropriate credit to the original author(s) and the source, provide a link to the Creative Commons licence, and indicate if changes were made. The images or other third party material in this article are included in the article's Creative Commons licence, unless indicated otherwise in a credit line to the material. If material is not included in the article's Creative Commons licence and your intended use is not permitted by statutory regulation or exceeds the permitted use, you will need to obtain permission directly from the copyright holder. To view a copy of this licence, visit http://creativecommons.org/licenses/by/4.0/.

\section{References}

Aikio S, Duncan RP, Hulme PE (2012) The vulnerability of habitats to plant invasion: disentangling the roles of propagule pressure, time and sampling effort. Glob Ecol Biogeogr 21:778-786. https://doi.org/10.1111/j.1466-8238. 2011.00711.x

Andersen KM, Naylor BJ, Endress BA, Parks CG (2015) Contrasting distribution patterns of invasive and naturalized non-native species along environmental gradients in a semi-arid montane ecosystem. Appl Veg Sci 18:683-693. https://doi.org/10.1111/avsc. 12185

Araújo MB, Thuiller W, Williams PH, Reginster I (2005) Downscaling European species atlas distributions to a finer resolution: implications for conservation planning. Glob Ecol Biogeogr 14:17-30. https://doi.org/10.1111/j. 1466-822X.2004.00128.x

Arévalo JR, Delgado JD, Otto R et al (2005) Distribution of alien vs. native plant species in roadside communities along an altitudinal gradient in Tenerife and Gran Canaria (Canary Islands). Perspect Plant Ecol Evol Syst 7:185202. https://doi.org/10.1016/j.ppees.2005.09.003

Baessler C, Klotz S (2006) Effects of changes in agricultural land-use on landscape structure and arable weed vegetation over the last 50 years. Agr Ecosyst Environ 115:4350. https://doi.org/10.1016/j.agee.2005.12.007

Bailey JJ, Boyd DS, Hjort J et al (2017) Modelling native and alien vascular plant species richness: at which scales is geodiversity most relevant? Glob Ecol Biogeogr 26:763776. https://doi.org/10.1111/geb.12574

Bar-Massada A, Radeloff VC, Stewart SI (2014) Biotic and abiotic effects of human settlements in the wildland-urban interface. Bioscience 64:429-437. https://doi.org/10.1093/ biosci/biu039

Bartolucci F, Peruzzi L, Galasso G et al (2018) An updated checklist of the vascular flora native to Italy. Plant Biosyst Int J Deal Asp Plant Biol 152:179-303. https://doi.org/10. 1080/11263504.2017.1419996

Bartuszevige AM, Gorchov DL, Raab L (2006) The relative importance of landscape and community features in the invasion of an exotic shrub in a fragmented landscape. Ecography 29:213-222. https://doi.org/10.1111/j.2006. 0906-7590.04359.x

Basnou C, Iguzquiza J, Pino J (2015) Examining the role of landscape structure and dynamics in alien plant invasion from urban Mediterranean coastal habitats. Landsc Urban Plan 136:156-164. https://doi.org/10.1016/j.landurbplan. 2014.12.001

Boscutti F, Sigura M, Simone SD, Marini L (2018) Exotic plant invasion in agricultural landscapes: a matter of dispersal mode and disturbance intensity. Appl Veg Sci 21:250-257. https://doi.org/10.1111/avsc.12351

Boscutti F, Pellegrini E, Casolo V et al (2020) Cascading effects from plant to soil elucidate how the invasive 
Amorpha fruticosa L. impacts dry grasslands. J Veg Sci 31:667-677. https://doi.org/10.1111/jvs.12879

Botham MS, Rothery P, Hulme PE et al (2009) Do urban areas act as foci for the spread of alien plant species? An assessment of temporal trends in the UK. Divers Distrib 15:338-345. https://doi.org/10.1111/j.1472-4642.2008. 00539. $\mathrm{x}$

Buccheri M, Boscutti F, Pellegrini E, Martini F (2019) LA flora aliena nel friuli venezia giulia alien flora in friuli venezia giulia. Gortania 40:7-78

Cabra-Rivas I, Saldaña A, Castro-Díez P, Gallien L (2016) A multi-scale approach to identify invasion drivers and invaders' future dynamics. Biol Invasions 18:411-426. https://doi.org/10.1007/s10530-015-1015-z

Campos JA, Biurrun I, García-Mijangos I et al (2013) Assessing the level of plant invasion: a multi-scale approach based on vegetation plots. Plant Biosyst Int J Deal Asp Plant Biol 147:1148-1162. https://doi.org/10.1080/11263 504.2013.861538

Čeplová N, Lososová Z, Kalusová V (2017) Urban ornamental trees: a source of current invaders; a case study from a European City. Urban Ecosyst 20:1135-1140. https://doi. org/10.1007/s11252-017-0665-2

Chaplin-Kramer R, O'Rourke ME, Blitzer EJ, Kremen C (2011) A meta-analysis of crop pest and natural enemy response to landscape complexity. Ecol Lett 14:922-932. https://doi.org/10.1111/j.1461-0248.2011.01642.x

Chen C, Wu S, Meurk CD et al (2017) Effects of local and landscape factors on exotic vegetation in the riparian zone of a regulated river: Implications for reservoir conservation. Landsc Urban Plan 157:45-55. https://doi.org/10. 1016/j.landurbplan.2016.06.003

Chytrý M, Maskell LC, Pino J et al (2008) Habitat invasions by alien plants: a quantitative comparison among Mediterranean, subcontinental and oceanic regions of Europe. J Appl Ecol 45:448-458. https://doi.org/10.1111/j.13652664.2007.01398.x

Cilliers SS, Williams NSG, Barnard FJ (2008) Patterns of exotic plant invasions in fragmented urban and rural grasslands across continents. Landsc Ecol 23:1243-1256. https://doi.org/10.1007/s10980-008-9295-7

Dainese M, Aikio S, Hulme PE et al (2017) Human disturbance and upward expansion of plants in a warming climate. Nat Clim Chang 7:577-580. https://doi.org/10.1038/nclim ate 3337

Davis MA, Grime JP, Thompson K (2000) Fluctuating resources in plant communities: a general theory of invasibility. J Ecol 88:528-534. https://doi.org/10.1046/j. 1365-2745.2000.00473.x

Follak S, Eberius M, Essl F et al (2018) Invasive alien plants along roadsides in Europe. EPPO Bull 48:256-265. https://doi.org/10.1111/epp.12465

Foxcroft LC, Richardson DM, Rouget M, MacFadyen S (2009) Patterns of alien plant distribution at multiple spatial scales in a large national park: implications for ecology, management and monitoring. Divers Distrib 15:367-378. https://doi.org/10.1111/j.1472-4642.2008.00544.x

Galasso G, Conti F, Peruzzi L et al (2018) An updated checklist of the vascular flora alien to Italy. Plant Biosyst Int J Deal Asp Plant Biol 152:556-592. https://doi.org/10. 1080/11263504.2018.1441197
Gavier-Pizarro GI, Radeloff VC, Stewart SI et al (2010) Housing is positively associated with invasive exotic plant species richness in New England, USA. Ecol Appl 20:19131925. https://doi.org/10.1890/09-2168.1

Geppert C, Boscutti F, Bella GL et al (2021) Contrasting response of native and non-native plants to disturbance and herbivory in mountain environments. J Biogeogr 48:1594-1605. https://doi.org/10.1111/jbi.14097

González-Moreno P, Pino J, Carreras D et al (2013) Quantifying the landscape influence on plant invasions in Mediterranean coastal habitats. Landsc Ecol 28:891-903. https:// doi.org/10.1007/s10980-013-9857-1

Guirado M, Pino J, Rodà F (2006) Understorey plant species richness and composition in metropolitan forest archipelagos: effects of forest size, adjacent land use and distance to the edge. Glob Ecol Biogeogr 15:50-62. https:// doi.org/10.1111/j.1466-822X.2006.00197.x

Guisan A, Lehmann A, Ferrier S et al (2006) Making better biogeographical predictions of species' distributions. J Appl Ecol 43:386-392. https://doi.org/10.1111/j.13652664.2006.01164.x

Guo W-Y, van Kleunen M, Pierce S et al (2019) Domestic gardens play a dominant role in selecting alien species with adaptive strategies that facilitate naturalization. Glob Ecol Biogeogr 28:628-639. https://doi.org/10. 1111/geb.12882

Hansen MJ, Clevenger AP (2005) The influence of disturbance and habitat on the presence of non-native plant species along transport corridors. Biol Cons 125:249-259. https:// doi.org/10.1016/j.biocon.2005.03.024

Hastings A, Cuddington K, Davies KF et al (2005) The spatial spread of invasions: new developments in theory and evidence. Ecol Lett 8:91-101. https://doi.org/10.1111/j.14610248.2004.00687.x

Hulme PE (2005) Nursery crimes: agriculture as victim and perpetrator in the spread of invasive species. Crop science and technology 733-740

Jauni M, Hyvönen T (2010) Invasion level of alien plants in semi-natural agricultural habitats in boreal region. Agr Ecosyst Environ 138:109-115. https://doi.org/10.1016/j. agee.2010.04.007

Krummel JR, Gardner RH, Sugihara G et al (1987) Landscape patterns in a disturbed environment. Oikos 48:321-324. https://doi.org/10.2307/3565520

Kühn I, Wolf J, Schneider A (2017) Is there an urban effect in alien plant invasions? Biol Invasions 19:3505-3513. https://doi.org/10.1007/s10530-017-1591-1

Kumar S, Stohlgren TJ, Chong GW (2006) Spatial heterogeneity influences native and nonnative plant species richness. Ecology 87:3186-3199. https://doi.org/10.1890/00129658(2006)87[3186:SHINAN]2.0.CO;2

Lambdon PW, Pysek P, Basnou C et al (2008) Alien flora of Europe: species diversity, temporal trends, geographical patterns and research needs. Preslia 80:101-149

Lázaro-Lobo A, Ervin GN (2019) A global examination on the differential impacts of roadsides on native vs. exotic and weedy plant species. Glob Ecol Conserv 17:e0555. https://doi.org/10.1016/j.gecco.2019.e00555

Lizée M-H, Manel S, Mauffrey J-F et al (2012) Matrix configuration and patch isolation influences override the species-area relationship for urban butterfly communities. 
Landsc Ecol 27:159-169. https://doi.org/10.1007/ s10980-011-9651-x

Lonsdale WM (1999) Global patterns of plant invasions and the concept of invasibility. Ecology 80:1522-1536. https:// doi.org/10.1890/0012-9658(1999)080[1522:GPOPIA]2.0. $\mathrm{CO} ; 2$

Malavasi M, Carboni M, Cutini M et al (2014) Landscape fragmentation, land-use legacy and propagule pressure promote plant invasion on coastal dunes: a patch-based approach. Landsc Ecol 29:1541-1550. https://doi.org/10. 1007/s10980-014-0074-3

Marco A, Lavergne S, Dutoit T, Bertaudiere-Montes V (2010) From the backyard to the backcountry: how ecological and biological traits explain the escape of garden plants into Mediterranean old fields. Biol Invasions 12:761-779. https://doi.org/10.1007/s10530-009-9479-3

Martin EA, Seo B, Park C-R et al (2016) Scale-dependent effects of landscape composition and configuration on natural enemy diversity, crop herbivory, and yields. Ecol Appl 26:448-462. https://doi.org/10.1890/15-0856

Maskell LC, Bullock JM, Smart SM et al (2006) The distribution and habitat associations of non-native plant species in urban riparian habitats. J Veg Sci 17:499-508. https://doi. org/10.1111/j.1654-1103.2006.tb02471.x

McDougall KL, Lembrechts J, Rew LJ et al (2018) Running off the road: roadside non-native plants invading mountain vegetation. Biol Invasions 20:3461-3473. https://doi.org/ $10.1007 / \mathrm{s} 10530-018-1787-\mathrm{z}$

McGarigal K, Marks BJ (1995) FRAGSTATS: spatial pattern analysis program for quantifying landscape structure. Gen Tech Rep PNW-GTR-351 Portland, OR: US Department of Agriculture, Forest Service, Pacific Northwest Research Station 122 p 351:. https://doi.org/10.2737/ PNW-GTR-351

McLean P, Gallien L, Wilson JRU et al (2017) Small urban centres as launching sites for plant invasions in natural areas: insights from South Africa. Biol Invasions 19:3541-3555. https://doi.org/10.1007/s10530-017-1600-4

Milbau A, Stout JC, Graae BJ, Nijs I (2009) A hierarchical framework for integrating invasibility experiments incorporating different factors and spatial scales. Biol Invasions 11:941-950. https://doi.org/10.1007/s10530-008-9306-2

Milne BT (1988) Measuring the fractal geometry of landscapes. Appl Math Comput 27:67-79. https://doi.org/10. 1016/0096-3003(88)90099-9

Montti L, Carrillo VP, Gutiérrez-Angonese J et al (2017) The role of bioclimatic features, landscape configuration and historical land use in the invasion of an Asian tree in subtropical Argentina. Landsc Ecol 32:2167-2185. https:// doi.org/10.1007/s10980-017-0563-2

Moser D, Zechmeister HG, Plutzar C et al (2002) Landscape patch shape complexity as an effective measure for plant species richness in rural landscapes. Landsc Ecol 17:657669. https://doi.org/10.1023/A:1021513729205

O'Neill RV, Krummel JR, Gardner RH et al (1988) Indices of landscape pattern. Landsc Ecol 1:153-162. https://doi.org/ 10.1007/BF00162741

O'Reilly-Nugent A, Palit R, Lopez-Aldana A et al (2016) Landscape effects on the spread of invasive species. Curr Landsc Ecol Rep 1:107-114. https://doi.org/10.1007/ s40823-016-0012-y
Ohlemüller R, Walker S, Bastow Wilson J (2006) Local vs regional factors as determinants of the invasibility of indigenous forest fragments by alien plant species. Oikos 112:493-501. https://doi.org/10.1111/j.0030-1299.2006. 13887.x

Pauchard A, Shea K (2006) Integrating the study of nonnative plant invasions across spatial scales. Biol Invasions 8:399-413. https://doi.org/10.1007/s10530-005-6419-8

Pellegrini E, Boscutti F, Alberti G et al (2021a) Stand age, degree of encroachment and soil characteristics modulate changes of $\mathrm{C}$ and $\mathrm{N}$ cycles in dry grassland soils invaded by the N2-fixing shrub Amorpha fruticosa. Sci Total Environ 792:148295. https://doi.org/10.1016/j.scitotenv. 2021.148295

Pellegrini E, Buccheri M, Martini F, Boscutti F (2021b) Agricultural land use curbs exotic invasion but sustains native plant diversity at intermediate levels. Sci Rep 11:8385. https://doi.org/10.1038/s41598-021-87806-7

Polce C, Kunin WE, Biesmeijer JC et al (2011) Alien and native plants show contrasting responses to climate and land use in Europe. Glob Ecol Biogeogr 20:367-379. https://doi.org/10.1111/j.1466-8238.2010.00619.x

Poldini L (2002) Nuovo atlante corologico delle piante vascolari nel Friuli Venezia Giulia. Regione Autonoma Friuli Venezia Giulia. Azienda Parchi e Foreste regionali and Università degli Studi di Trieste, Dipartimento di biologia, Udine

Preston CD, Pearman DA, Hall AR (2004) Archaeophytes in Britain. Bot J Linn Soc 145:257-294. https://doi.org/10. 1111/j.1095-8339.2004.00284.x

Pyšek P (1998) Alien and native species in Central European urban floras: a quantitative comparison. J Biogeogr 25:155-163. https://doi.org/10.1046/j.1365-2699.1998. 251177.x

Pyšek P, Hulme PE, Simberloff D et al (2020) Scientists' warning on invasive alien species. Biological Rev n/a. https://doi.org/10.1111/brv.12627

R Core Team (2020) R: A language and environment for statistical computing. R Foundation for Statistical Computing. Vienna, Austria

Riitters K, Potter K, Iannone BV et al (2018) Landscape correlates of forest plant invasions: a high-resolution analysis across the eastern United States. Divers Distrib 24:274-284. https://doi.org/10.1111/ddi.12680

Säumel I, Kowarik I (2010) Urban rivers as dispersal corridors for primarily wind-dispersed invasive tree species. Landsc Urban Plan 94:244-249. https://doi.org/10. 1016/j.landurbplan.2009.10.009

Sheppard CS, Brendel MR (2021) Competitive ability of native and alien plants: effects of residence time and invasion status. NeoBiota 65:47-69. https://doi.org/10. 3897/neobiota.65.63179

Simberloff D, Martin J-L, Genovesi P et al (2013) Impacts of biological invasions: what's what and the way forward. Trends Ecol Evol 28:58-66

Song I-J, Hong S-K, Kim H-O et al (2005) The pattern of landscape patches and invasion of naturalized plants in developed areas of urban Seoul. Landsc Urban Plan 70:205-219. https://doi.org/10.1016/j.landurbplan.2003. 10.018 
Stohlgren TJ, Jarnevich C, Chong GW, Evangelista PH (2006) Scale and plant invasions: A theory of biotic acceptance. Preslia 78:22

van Kleunen M, Essl F, Pergl J et al (2018) The changing role of ornamental horticulture in alien plant invasions. Biol Rev 93:1421-1437. https://doi.org/10.1111/brv.12402

Vilà M, Hulme P (eds) (2017) Impact of biological invasions on ecosystem services. Springer International Publishing

Vilà M, Ibáñez I (2011) Plant invasions in the landscape. Landscape Ecol 26:461-472. https://doi.org/10.1007/ s10980-011-9585-3

Vilà M, Pino J, Font X (2007) Regional assessment of plant invasions across different habitat types. J Veg Sci 18:3542. https://doi.org/10.1111/j.1654-1103.2007.tb02513.x

Vilà M, Basnou C, Pyšek P et al (2010) How well do we understand the impacts of alien species on ecosystem services? A pan-European, cross-taxa assessment. Front Ecol Environ 8:135-144. https://doi.org/10.1890/080083

Vilà M, Espinar JL, Hejda M et al (2011) Ecological impacts of invasive alien plants: a meta-analysis of their effects on species, communities and ecosystems. Ecol Lett 14:702708. https://doi.org/10.1111/j.1461-0248.2011.01628.x

Vitti S, Pellegrini E, Casolo V et al (2020) Contrasting responses of native and alien plant species to soil properties shed new light on the invasion of dune systems. J Plant Ecol 13:667-675. https://doi.org/10.1093/jpe/rtaa0 52 von der Lippe M, Kowarik I (2008) Do cities export biodiversity? Traffic as dispersal vector across urban-rural gradients. Divers Distrib 14:18-25. https://doi.org/10.1111/j. 1472-4642.2007.00401.x

Yates ED, Levia DF, Williams CL (2004) Recruitment of three non-native invasive plants into a fragmented forest in southern Illinois. For Ecol Manage 190:119-130. https:// doi.org/10.1016/j.foreco.2003.11.008

Zając M, Zając A, Tokarska-Guzik B (2009) Extinct and endangered archaeophytes and the dynamics of their diversity in Poland. Biodivers Res Conserv 13:17-24. https://doi.org/10.2478/v10119-009-0004-4

Zeeman BJ, Minden V, Morgan JW (2018) Non-native plant cover and functional trait composition of urban temperate grasslands in relation to local- and landscape-scale road density. Biol Invasions 20:3025-3036. https://doi.org/10. 1007/s10530-018-1756-6

Publisher's Note Springer Nature remains neutral with regard to jurisdictional claims in published maps and institutional affiliations. 